Original Research

\title{
Spatial Environmental Modeling for Wildfire Progression Accelerating Extent Analysis Using Geo-Informatics
}

\author{
Naruset Prasertsri, Patiwat Littidej* \\ Research Unit of Geo-Informatics for Local Development, Department of Geo-Informatics Faculty of Informatics, \\ Mahasarakham University, Thailand
}

Received: 15 September 2019

Accepted: 9 December 2019

\begin{abstract}
The fire situation during the dry season of Thailand, in the last 10 years, has become more severe. The Tad Sung Forest Park area has reported the intensity of wildfires for the past 7 years. This research has applied the geographic weighted regression (GWR) model to generate a spatial relationship analysis model for wildfires. This research aims to create a spatial model to analyze the risk of hazardous areas against wildfire and to analyze the factors that affect forest fire risks in order to protect against wildfires. The service area $\left(S A_{L Y}\right)$ model was obtained through the first approach. The wildfire-GWR results of the study showed that the model can predict at the $\mathrm{R}^{2}$ level greater than $82 \%$ and varies according to the sub-area boundaries. Factors affecting the acceleration of wildfires are (positive coefficient) the digital elevation model (DEM), normalized burn ratio (NBR), land surface temperature (LST) and (negative coefficient) normalized difference vegetation index (NDVI), slope and aspect. In addition, the distance from the road factor has little effect on wildfire intensity in most areas. The results of the research are used to create a risk-sensitive map of wildfires through surveillance by importing the independent variable factors in the model and using it as a prototype of the same kind of space.
\end{abstract}

Keywords: forest fire, wildfire, service area, geographic weighted regression (GWR), spatial model, geo-informatics

\section{Introduction}

Forest fires or wildfires are natural disasters that significantly affect a wide variety of natural resources such as forests and animals. A number of factors that cause wildfires including human-caused wildfire and

*e-mail: patiwat.1@msu.ac.th natural factors [1]. Human-caused wildfire is one of the major concerns as more than $80 \%$ of wildfires in Thailand result from human activities [1]. In Thailand, a study provided by the Thai Royal Forest (TRF) shows that the damage from forest fires is increasingly expansive [1]. The indicator of the TRF Wildfire report is analyzed from the heat point of the measurement with the MODIS of the Terra and Aqua satellites, and is expressed as an unusually high heat point (Hotspots) in the whole area of Thailand (data range 2017-2019). 
The appearance of a higher heat point in the northern conservation forest area found 22,071 the northeastern area of Thailand, found 4,721 points by the area of both regions, and this region has a lot of terrain with a steep area of space and the boundaries of neighboring countries than other regions. The central and southern areas found less wildfire than other regions, namely 3,716 and 504 points respectively. This figure indicates the explicit spread of wildfires in Thailand, which can lead to the direct and indirect impact of substantial forest damage, including the degradation of soil quality, air pollution, and a lack of clean water. That is, the effect of wildfire directly on the species is that the tree burns the wildfires (fire scars) and causes the tree to die, but for indirect effects, such as causing the growth of Trees to decrease, and cause damage to the roots by fire will damage the stem by the fire to burn the peel and cause the peel dropped from the trunk easily. In addition, the fire will burn the root leaves and tissue, the growth of the trunk causes the tree's growth to decline, if the tree has been very damaged, for example, the fallen leaves can die in the end, but if the tree does not die immediately, it will gradually dry and allow insects to break the tree along the burns. With the progression of forest fires in the conservation forest area of Thailand, it is necessary to study and find precise tracking guidelines and use both the variables associated with wildfire in the area and the appropriate replicas.

The spread of a wildfire can be determined by a variety of factors such as types of forests, physical landscapes, local seasons, and areas or locations [26]. The factors of each area are susceptible to different forest fires, as well as the models used being different. Similar factors that are commonly used to research the progression of wildfire are DEM and slope, and the use of variables and wind direction create the distribution model of wildfire. These factors can be used to determine or even estimate the damage by a wildfire in a particular area of various methods carried out by [7-10].

Wildfires or forest fires typically occur in vegetation and burn natural fuels, enabling them to quickly spread and damage natural resources. These issues have gained increasing attention among researchers. The main objective of this section, therefore, is to provide an overview of the understanding of the effects of forest fires on natural vegetation and how forest fires can also act as a form of forest management. Omid et al. [2] studied and developed a risk assessment system for forest fires. The study evaluated the causality and factors of forest fires, including underlining a scheme to prevent the devastating effects of uncontrolled wildfire. It applied a geographical information system by analyzing essential local factors in that area that can result in wildfires, such as slope, height, normalized difference vegetation index (NDVI), direction of slope, roads, rivers, villages, land use, and economic and social factors. The work applied this informational system to predict the risks of wildfire in the area [11-13]. There is also research that uses the characteristics of a variable that is associated with the spread of wildfire that can be analyzed for other types of disaster risks, as well as variables of height and slope that are the main variables that affect the risks, such as landslides, from a wide range of research by [14-18]. In addition, it refers to the research of $[2,19]$ and conducted a research study using remote sensing data and geographical information systems to study the risks of wildfire used satellite information regarding (i) land use change, (ii) roads, (iii) agricultural fields, (iv) built-up areas, and (v) slope to generate overlay information and then report the risks in the area. Wigtil et al. [20] applied land use and land cover (LULC) and geographical information to study and analyze the essential factors that affect the location of wildfires resulting in degeneration and damage to forests and pollution in the province in both time series and spatial information (based on Landsat, NDVI, EVI and MODIS data). Omid et al. [2] proposed a generic risk assessment framework and resource management for wildfires. The proposed framework is aimed at capping different types of modelling approaches that are able to characterize wildfire likelihood and intensity, fire effect, and the relative significant value of resources that could be affected by wildfire. Assessing wildfire risk is a crucial component of wildfire management and risk mitigation planning. A spatial, quantitative characterization of wildfire risk allows for identification of areas on the landscape where aggressive treatment might be cost-effective.

Previous research, such as [21-29] illustrated how the normalized burn ratio (NBR) and normalized difference vegetation index (NDVI) are the most commonly applied indices. NBR has been extensively used in western U.S. coniferous forests according to [30-35], but less so in tropical savannas [36-38], Mediterranean ecosystems [39-41] and boreal forests $[42,43]$. Very few published studies have applied NBR in mapping fire severity patterns in wildfires in the temperate eucalyptus-dominated forests of Australia [44-47], largely because of: (1) the general unavailability of usable satellite images that are cloudfree; (2) the availability of other imagery that typically lacks a shortwave infrared (SWIR) band required for NBR computation [43], and (3) the availability of higher resolution imagery that is more attractive for fire severity assessments. It has some research that uses geographic weighted regression (GWR) to study spatial problems such as in [48, 49]. At present, research has used new tools such as Omid et al. [2], who studied the current use of the new tools and methods that must be applied to improve wildfire management; in this regard, employing artificial intelligence (AI) may be considered an effective solution. AI technologies like machine learning (ML), which is a computational study of algorithms, can help scientists generate solid models for monitoring wildfires and discovering variances in real time [50]. In automated learning approaches, ML 
acquires information from data, and ML algorithms receive the input data and implement statistical analyses to calculate new entries. The spatial prediction of an area's susceptibility to any natural hazard requires data from geographic information systems (GIS) and remote sensing (RS) sources. Furthermore, to using relevant input data to wildfire susceptibility, an appropriate approach is required to effectively produce susceptibility maps [51]. Several studies have been conducted to develop a spatial prediction of wildfire susceptibility using GIS and RS implemented in different approaches such as modified analytical hierarchy process (M-AHP) and Mamdani fuzzy logic models by Hamid et al. [52], and the analytical network process (ANP) [53]. However, recently, ML approaches have achieved fairly good results in various natural hazard susceptibility mapping studies. Some common ML approaches were applied in a wide range of studies in the field of wildfire modelling and susceptibility mapping such as an artificial neural network (ANN) [54], support vector machines (SVM) [55-57], and random forest (RF) [58, 59]. However, this research has included many of the advantages of spatial replicas and the import of multiple independent variables to create a model in a different area with the GWR model. However, the method to create an appropriate spatial unit to the GWR model will cause the model to anticipate more precisely than other methods and to qualify only those that have fewer tolerances to maintain a replica.

Past research shows no studies using GWR models to create wildfires extent analysis in this way. The modelling of forest fire risk areas is different based on the nature of the area, as there are both possible human behaviors and the terrain that promotes risk. Therefore, the main objectives of this work are: i) modelling the service area of wildfire spreading (objective 1 is obtained by the $S A_{L Y}$ model) and ii) GWR modelling to analyze influential environmental factors to wildfire spreading and mapping the factors that are related to wildfire risk. The model is a local operational process, making it more precise than other methods.

This work proposes a novel system that utilizes geographical and physical information to perform a risk analysis of areas experiencing wildfires (in the forest park of Kudwa, Kalasin province of Thailand). The information from the analysis can be used to implement a risk management system that can protect the area from unexpected wildfires. This work applies to a number of geographical information points concerning the area: i.e., hot spot, digital evaluation model (DEM), area slope, aspect, normalized burn ratio (NBR), normalized difference vegetation index (NDVI), surface radiance temperature (SRT), roads, trek routes, the distances from the nearest roads, and the distances from the nearest villages $[2,19-22]$.

\section{Material and Methods}

\section{Study Area}

This work applies physical information and the GWR model to perform a risk analysis of areas experiencing wildfires (in the forest park of Kudwa, Kalasin, Thailand). The data were collected using remote sensing techniques to acquire LANDSAT 8 OLI with a ground resolution of $30 \mathrm{~m}$ in February during 2013-2019. Using standard false color composition, NIR, Red and Green were mixed to generate final images. Sub-images were determined and the information of previous fire locations was annotated in the sub-images.

The northeastern region Thailand is the second largest forest area in the country. The nature of the forest in the region is one of the major factors that causes the spread of wildfires. The deciduous, mixed deciduous, and dry evergreen forest are three major types of forest in the region. In addition, the people living in the region are local people who have unique ways of life. Therefore, their local activities can also possibly cause unexpected wildfires. The study area is not high-mountain landscape, and is suitable for the locals to carry out forest agriculture and farming (such as cows) - considered to be one of the main potential factors of forest fires in the area. In addition to the image data, field work was carried out to collect physical information in the area. There are 29 survey points marked in this study, the framework of the study is depicted in Fig. 1 and demonstrated in Fig. 2.

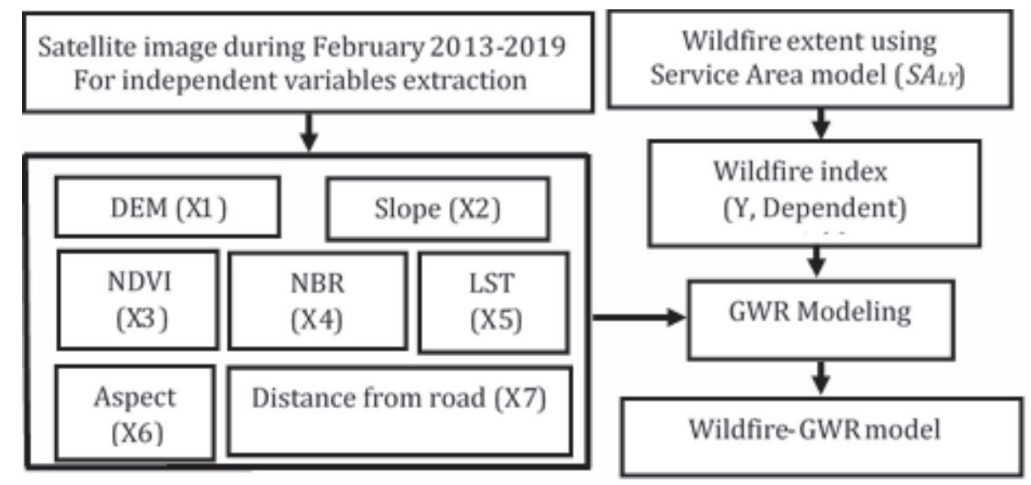

Fig. 1. Framework of the GWR modelling in the study. 


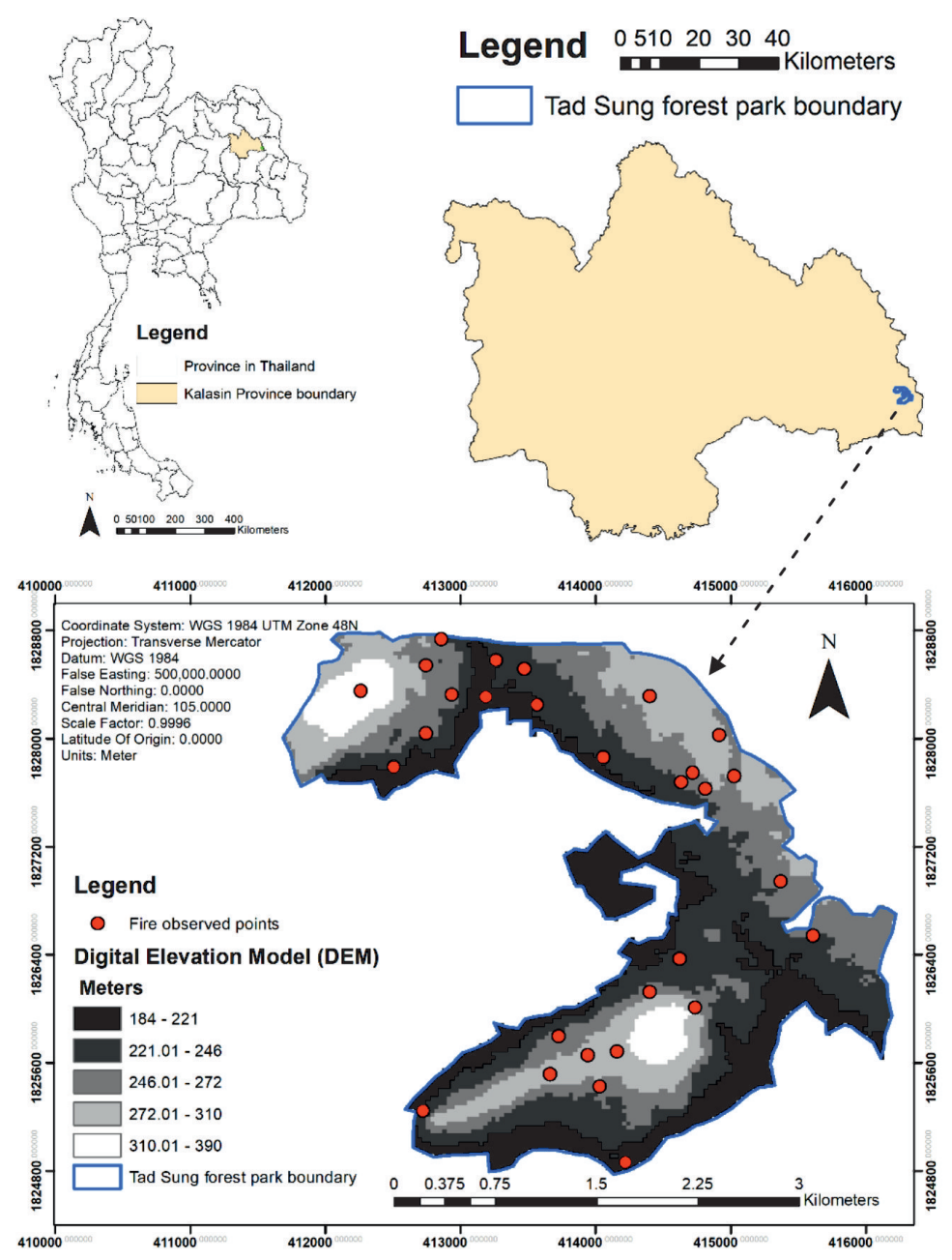

Fig. 2. Map of the digital elevation model (DEM) and observed wildfire points in the study area.

\section{Determining Fire Factors in Tad Sung Forest Park (Environmental Independent Variables)}

From the reports of forest officials in the national park, we found that the fire factors are examined from the previous fire points so as to estimate the sensitivity of these area points in terms of the risk of forest fire in the study area. There are 7 geographical factors analyzed in this study, which are as follows:

1) Digital elevation model (DEM): this information signifies change of elevation in areas in digital format. Using raster GIS, each item of the data grid represents the height of the land. With this information, DEM can be determined as one of the factors of forest fires. In high lands (like mountains), strong winds can spread fire more quickly than on lower ground. This research has created an equation for the DEM indices to fit in the analysis, as shown in (Eq. 1).

$$
A D_{j}=\sum_{i=1}^{n} D_{i} / N_{j}
$$

...where $A D_{j}$ is the average of DEM that is calculated from the proportion of the summation of cell any $i$ in sub-basin any $j$ and $N_{j}$ is the total number of cell any $i$ in sub-basin any $j$.

2) Slope: DEM (in raster format) is used to estimate the average level of slopes in the area. Slope for a particular area is calculated as the maximum rate of change of elevation between the area and its surroundings. Slope imposes the direction (slope aspect) and the speed of the spread of the fire, which is usually aligned along the slope of an area. The proper attribute of the slope was calculated in (Eq. 2):

$$
A S_{j}=\sum_{i=1}^{n} S_{i} / N_{j}
$$

... where $A S_{j}$ is the average of the slope in degree units that is calculated from the proportion of the summation of cell any $i$ in sub-basin any $j$ and $N_{j}$ is the total number of cell any $i$ in sub-basin any $j$.

3) Aspect: this factor indicates the areas of illumination based on the steepest downslope direction of the land surfaces. The measurement is determined clockwise, ranging from 0 to 360 . Each of the grid cells in the data is embedded with this slope aspect. For flat areas (flat slope), the slope aspect is initialized to 
-1 . With slope aspect information, mountain areas face the impression of illumination that will be drier, and this is enough to burn - especially when coupled with wind flow direction, when forest fires can spread more quickly. The aspect index is determined as (Eq. 3):

$$
A A_{j}=\sum_{i=1}^{n} A_{i k} x L_{i k} / N_{j}
$$

...where $A_{j}$ is the average of the aspect that is calculated from the proportion of the sum product of cell direction any $k$ and $L_{i k}$ is the length of aspect direction any $k$ cell any $i$ in sub-basin any $j$, and $N_{j}$ is the total number of cell any $i$ in sub-basin any $j$. This attribute is classified as 8 columns along 8 directions (north, northeast, east, southeast, south, southwest, west, and northwest).

4) Normalized difference vegetation index (NDVI): this index delineates the variation and density of vegetation in a given area. The high density will be illustrated by dark-colored shades, and lighter otherwise. Areas with low NDVI are sensitive and at higher risk of forest fire, and the fire can spread rapidly in these areas. Models are usually in the form of $(\mathrm{NIR}-\mathrm{R}) /(\mathrm{NIR}+\mathrm{R})$. In Landsat $8, \mathrm{NDVI}=($ Band 5 - Band 4) / (Band $5+$ Band 4). In the study was formulated in (Eq. 4).

$$
A N D V I_{j}=\sum_{i=1}^{n} N D V I_{i} / N_{j}
$$

...where $A N D V I_{j}$ is the average of NDVI that is calculated from the proportion of the summation of cell any $i$ in sub-basin any $j$ and $N_{j}$ is the total number of cell any $i$ in sub-basin any $j$.

5) Normalized burn ratio (NBR) is used for the hot-spot bodies' analysis. NBR is calculated as a ratio between the NIR and SWIR values in a traditional fashion. The NBR index can be analyzed for the hotspot of the soil surface. Areas with less surface moisture are more vulnerable to the progression of fire than areas with other characteristics. Models are usually in the form of (NIR - SWIR) / (NIR + SWIR). In Landsat 8, $\mathrm{NBR}=($ Band $5-$ Band 7$) /($ Band $5+$ Band 7$)$. In the study formulated in (Eq. 5).

$$
A N B R_{j}=\sum_{i=1}^{n} S_{i} / N_{j}
$$

...where $A N B R_{j}$ is the average of NBR that is calculated from the proportion of the summation of cell any $i$ in sub-basin any $j$ and $N_{j}$ is the total number of cell any $i$ in sub-basin any $j$.

6) Land surface temperature (LST): surface temperature demonstrates the level of heat accumulated on the land surface. LST is directly related to forest fires. In general, it can serve to index the severity of a forest fire. The SRT model uses Landsat 8 data [60] as
(Eq. 6), where $T=$ At-satellite brightness temperature $(\mathrm{k}), L_{2}=$ spectral radiance (Watts/ $\left(\mathrm{m}^{2 *} \mathrm{srad}^{*} \mu \mathrm{m}\right)$ ), $K_{1}$ and $K_{2}=$ Band-specific thermal conversion consistent with the metadata $\left(K_{1}\right.$ and $K_{2}$ constant band $\mathrm{X}$ where $\mathrm{X}$ is the thermal band number) in the study that obtained the new index in (Eq. 7):

$$
\begin{gathered}
T=\frac{K_{2}}{\ln \left(\frac{K_{1}}{L_{\lambda}}+1\right)} \\
A L S T_{j}=\sum_{i=1}^{n} L S T_{i} / N_{j}
\end{gathered}
$$

...where $A L S T_{j}$ is the average of $L S T$ that is calculated from the proportion of the summation of cell any $i$ in sub-basin any $j$ and $N_{j}$ is the total number of cell any $i$ in sub-basin any $j$.

7) Distance from roads in the forest park: the behavior of villagers near the Tad Sung Forest Park area will involve coming to the resources inside the forest to sell, such as mushrooms, vegetables, firewood, etc. Villagers will use the wildfire method of setting fires to save the cost of saving the hemp, also causing the vegetation to regenerate again after burning. The mathematics of this variable are shown in (Eq. 8):

$$
A D I S_{j}=\sum_{i=1}^{n} D I S_{i j f}
$$

...where $A D I S_{j}$ is the average of distance that is calculated from the summation of the distance between road features any $i$ to wildfire point any $f$ in sub-basin any $j$.

\section{Progression Rate of Wildfire (Y, Dependent Variable)}

In the previous research a wide range of wildfires was examined, but in this study a wildfire index is created with the mathematical model as (Eq. 9) in order to determine the index as the variant as in the GWR model. The model recognizes the severity of the extent of the fire.

The wildfire index was constructed from the area of fire exploration over seven years. The dispersion of the forest fire exploration points is shown in (Eq. 9):

$$
\text { Wildfire }_{j}=\sum_{L=1}^{5} S A_{L Y}
$$

...where Wildfire is the burned area in service area any $j$ that is calculated from the summation of service areas $\left(S A_{L Y}\right)$. The area of fire is calculated from the analysis of the service area of wildfire extent from field observation and the $S A_{L Y}$ model using the overlay function of QGIS 3.6.0. The calculation of the impedance of the network 
is based on [61] research, used to find the extent of the area vulnerable to the severity of air pollution. The service area calculates the extent through the impedance values of the adjacent cell DEM values. This impedance value is generated from the concept that the fire will spread according to different heights. The higher the height, the faster the fire. The resistance value is created as the network of the numerical heights. Calculating the service area uses the network analysis functionality with the QGIS 3.6.0 program under the service area. This calculation is shown in (Eq. 10) and is an example of the $S A_{L Y}$ model shown in Fig. 3.

$$
S A_{L Y}(\text { impedance })=L_{i j} x\left|H_{i}-H_{j}\right|^{-1}
$$

...where $S A_{L Y}$ is the service area that is obtained from the impedance of link $L_{i j}$ which is the length of the link calculated from the distance between the central points of the cell. If the scene is vertical between the cells, the value is $30 \mathrm{~m}$; if oblique there is a value of $42 \mathrm{~m}$. $H_{i}$ is the altitude value of cell any $i . H_{j}$ is the altitude value of cell any $j$ that is around cell $i$.

An example of how the link's resistance is calculated is when the original link is $30 \mathrm{~m}$ long, when it is multiplied by the inverse of the absolute value of the difference in the height of the adjacent cells. The example defines a value of 10 , so the value impedance of the new link was normalized to 300 (30 x 10).

Assigning a variable to be able to analyze the service area will use the creation of the cut-off from the Time variable. From a query from TRF and DNP (Department of National Parks, Thailand) [1] to observe the issues of the movement time of fire relative to the speed in the northeastern forest area, it was found that factors affecting the severity of wildfire are various, such as the progression rate of fire (rate of spread), the intensity of fire, and the flame length, but these will vary depending on the nature of the area.

\section{GWR Modeling for Wildfire Spatial Relationship Analysis}

The dependent and independent variables within the spatial unit were considered. The polygon that is shown in Fig. 3 is based on the features input in GWR. Both variables are collected in this polygon. GWR is a local multivariate regression function for which the data samples are weighted on their spatial proximity. It produces a separate set of regression parameters for every observation across the study area. It therefore relaxes the assumption in traditional OLS models that the relationships (regression coefficients) between dependent and independent variables being modelled is constant across the study area, as seen in (Eq. 11). by Y (dependent $=$ Wildfire index):

$$
\begin{gathered}
\text { Wildfire }=\beta_{0}+\beta_{1}(\text { DEM })+\beta_{2}(\text { Slope }) \\
+\beta_{3}(\text { Ndvi })+\beta_{4}(N b r)+\beta_{5}(\text { Lst }) \\
+\beta_{6}(\text { Aspect })+\beta_{7}(\text { Dist })+\varepsilon
\end{gathered}
$$

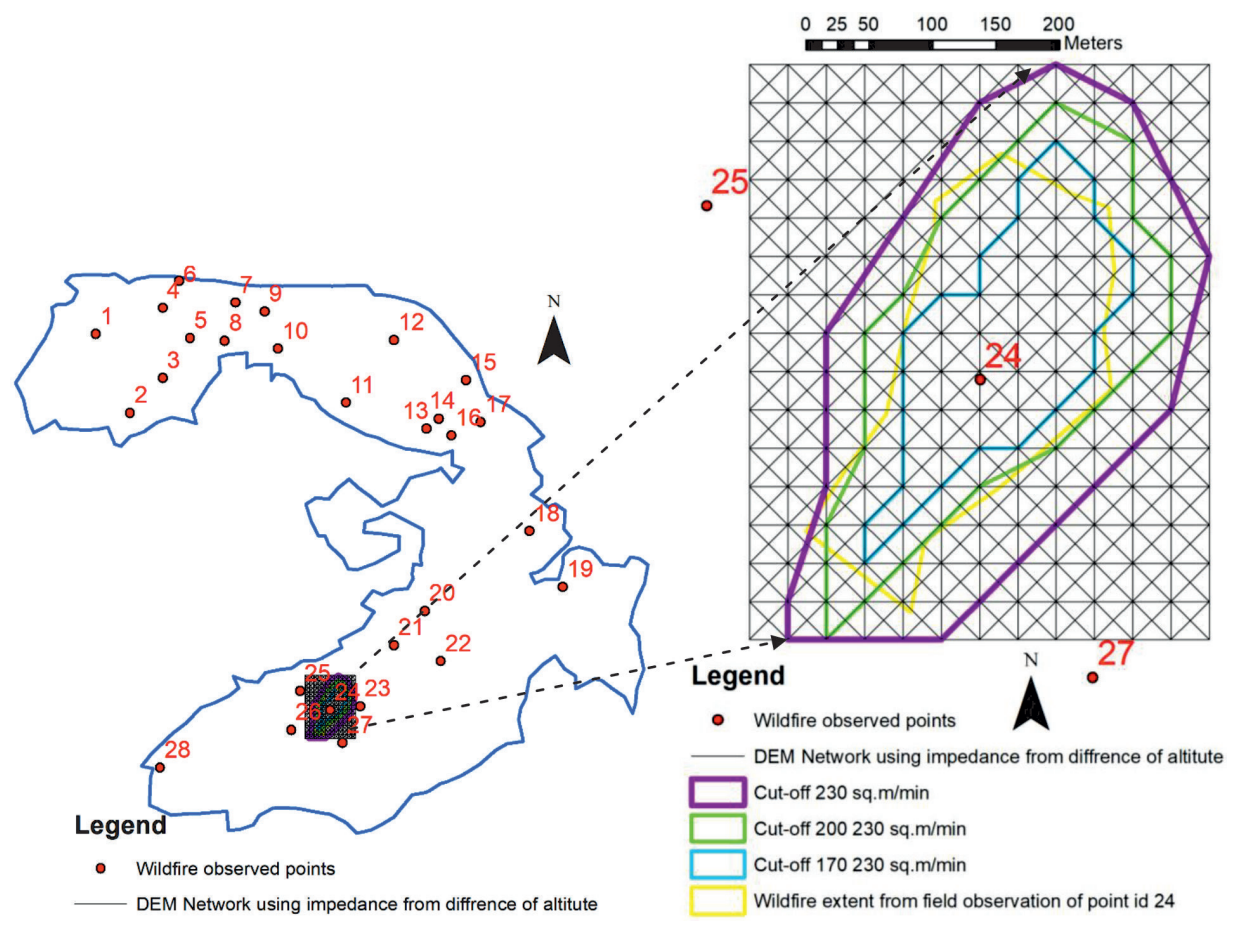

Fig. 3. Example of the results of the $S A_{L Y}$ model setting a cut-off at 170, 200 and $230 \mathrm{~m}^{2} /$ minute based on impedance from the DEM network. 
...where $y$ is the dependent variable, $x_{1}$ is the independent variable, $\beta_{0}$ and $\beta_{1}$ are the parameters to be estimated, $\varepsilon$ is a random error term, assumed to be normally distributed, $\beta_{0}$ is the intercept term, $\beta_{1}, \beta_{2}, \beta_{3}, \beta_{4}, \beta_{5}$, and $\beta_{6}$ are spatially varying coefficients of the average of the DEM index $\left(A D_{i}, X_{1}\right)$, slope $\left(A S_{i}, X_{2}\right)$, NDVI $\left(A N D V I_{j}\right.$, $\left.X_{3}\right)$, NBR $\left(A N B R_{j}, X_{4}\right), \operatorname{LST}\left(A L S T_{j}, X_{5}\right)$, aspect $\left(A A_{j}, X_{6}\right)^{\prime}$, distance from road $\left(A D I S_{j}, X_{7}\right)$ and $\varepsilon_{i}$ is an error term at point $i,\left(u_{i} v_{i}\right)$ representing the coordinates of the $i^{i t h}$ point in the study extent [48]. In this instance $\beta_{0}$ and $\beta_{1}$ are assumed to be constant across the region in classical ordinary least squares regression. Where there is any geographical variation in the relationships between $\mathrm{y}$ and both $\beta_{0}$ and $\beta_{1}$, it will be captured in the error term. When using Ordinary Least Squares (OLS), the parameters can be estimated by solving as (Eq. 12):

$$
\beta=\left(X^{T} X\right)^{-1} X^{T} \text { Wildfire }
$$

For geographically weighted regression, Fotheringham et al. [62] was used to incorporate the data in each polygon of observation into a regression model using a series of distance-related weights. The relationship between urban built-up areas and the location characteristics for a particular polygon, for example, is given a higher weight than for polygons far from that polygon.

The GWR model is fitted to the data using the QGIS 3.6.0 free software package, which allows for the use of a variety of calibration techniques to specify regression weights and to optimize bandwidth parameters. In this study, a fixed defined kernel with a bi-square function in which the bandwidth was determined by minimization of the Akaike information criterion (AIC), which is a criterion used to select the best model of the GWR model as a criterion based on the estimation of tolerances, combined with information of observations and the concept of finding values. The minimum of information to be used to adjust the estimate of forecasts to be more accurate. The result of a low-value AIC will cause the model to predict more accurately and accurately than a high value [49]. The reason is that the points of analysis used are in regular and equal sizes. The Monte Carlo test was also performed to determine the significance of the spatial variability in the local parameter estimates. The Monte Carlo test in this study made a selection of spatial non-stationarity variables that have a relationship with the variable, as it is eliminated from the model and expressed as a value (n/s), by selecting only the independent variable with a significant level using the value of P-value as a scorecard.

\section{Results and Discussion}

Service Area Approach for Wildfire Progression Accelerating Extent Analysis in Tad Sung Forest Park

The time simulation in the cut-off setting of the service area analysis function is determined by 28 field observation points during February 2013-2019.

Table 1. Results of wildfire extent analysis from field observations and the service area model.

\begin{tabular}{|c|c|c|c|c|c|c|c|c|c|}
\hline $\begin{array}{c}\text { Wild } \\
\text { fire } \\
\text { point }\end{array}$ & $\begin{array}{c}\text { Time to } \\
\text { extinguish } \\
\text { a fire } \\
\text { (minutes) }\end{array}$ & $\begin{array}{c}\text { Burned } \\
\text { area } \\
\text { (Sq.m) }\end{array}$ & $\begin{array}{c}\text { Fire sprea } \\
\text { ding } \\
\text { (Sq.m/ } \\
\text { minutes) }\end{array}$ & $\begin{array}{c}\text { Burned area } \\
\text { (Sq.m) } \\
\text { from } S A_{L Y}\end{array}$ & $\begin{array}{c}\text { Wild } \\
\text { fire } \\
\text { point }\end{array}$ & $\begin{array}{c}\text { Time to } \\
\text { extinguish } \\
\text { a fire } \\
\text { (minutes) }\end{array}$ & $\begin{array}{c}\text { Burned } \\
\text { area } \\
\text { (Sq.m) }\end{array}$ & $\begin{array}{c}\text { Fire sprea } \\
\text { ding } \\
\text { (Sq.m/ } \\
\text { minutes) }\end{array}$ & $\begin{array}{c}\text { Burned area } \\
\text { (Sq.m) } \\
\text { from } S A_{L Y}\end{array}$ \\
\hline 1 & 894 & 233168 & 261 & 262076 & 15 & 210 & 41998 & 200 & 49767 \\
\hline 2 & 186 & 35040 & 188 & 41864 & 16 & 222 & 43552 & 196 & 46250 \\
\hline 3 & 252 & 39849 & 158 & 49824 & 17 & 210 & 26509 & 126 & 34712 \\
\hline 4 & 240 & 49256 & 205 & 56174 & 18 & 282 & 84063 & 298 & 112872 \\
\hline 5 & 270 & 39496 & 146 & 44258 & 19 & 336 & 58846 & 175 & 82137 \\
\hline 6 & 288 & 29303 & 102 & 34935 & 20 & 252 & 33779 & 134 & 34974 \\
\hline 7 & 246 & 29643 & 121 & 41385 & 21 & 288 & 61530 & 214 & 60482 \\
\hline 8 & 240 & 29005 & 121 & 45119 & 22 & 270 & 71622 & 265 & 103506 \\
\hline 9 & 234 & 44261 & 189 & 45276 & 23 & 324 & 89045 & 275 & 133113 \\
\hline 10 & 324 & 74155 & 229 & 92556 & 24 & 258 & 43729 & 169 & 61297 \\
\hline 11 & 300 & 70746 & 236 & 92208 & 25 & 324 & 46819 & 145 & 77412 \\
\hline 12 & 450 & 93942 & 209 & 118474 & 26 & 306 & 57092 & 187 & 53827 \\
\hline 13 & 258 & 30387 & 118 & 37584 & 27 & 300 & 65069 & 217 & 97534 \\
\hline 14 & 180 & 34258 & 190 & 36078 & 28 & 252 & 71583 & 284 & 90554 \\
\hline
\end{tabular}


The cut-off value in the study area is $200 \mathrm{~m}^{2} /$ minute from the center of the field observation points. The area of fire exploration is captured, including the fire and time of the forest fire, as shown in Table 1 and Figure 4. The maximum value of burned area is equal to 233,168 $\mathrm{m}^{2}$ at wildfire point 1 . The minimum value equal to $26,509 \mathrm{~m}^{2}$ at wildfire point 17 is a high value spread in areas with altitude greater than $300 \mathrm{~m}$. The settings are such that the $S A_{L Y}$ model can be analyzed and must be configured for the cut-off. The average of fire spreading $=191$, but the $S A_{L Y}$ analysis requires the cut-off value to be greater than the average in order to cause the analysis result to be at least on the edge of the burned area to take over the scope of the other independent variables. The $S A_{L Y}$ model can predict the progression area of the fire spread $\left(\mathrm{m}^{2} /\right.$ minutes). The level of precision at $\mathrm{R}^{2}$ (adjusted) $=0.94$, compared to the exploration of the burned area $\left(\mathrm{m}^{2}\right)$ from the $S A_{L Y}$ model. The relationship equation is: (burned area) $=262,076+0.762$ (burned area from $\left.S A_{L Y}\right)$.
The $S A_{L Y}$ model analysis can accurately predict the fire area in areas with varying altitudes. The $S A_{L Y}$ model needs to design the impedance values to suit the style of the area. That is, if the area is very steep, it is necessary to weight the sub-areas, because it is necessary to design the resistance to measure the boundary of the forest fires. However, this is only an analysis of the boundaries of forest fires. In further analysis it analyzes the variables that influence the wildfire and accelerates the wildfire into the area quickly.

\section{Spatial Environmental Factors Variation to Wildfire}

The GWR model determines the sub-area boundary (spatial unit) because it is a local operation in the spatial statistical process for extracting the independent variable values consisting of DEM index $\left(A D j\right.$., $\left.X_{l}\right)$, slope $\left(A S j, X_{2}\right)$, NDVI $\left(A N D V I j, X_{3}\right)$, NBR $(A N B R j$, $\left.X_{4}\right)$, LST $\left(A L S T j, X_{5}\right)$, aspect $\left(A A j, X_{6}\right)$, and distance from road $\left(A D I S j, X_{7}\right)$, respectively. The 7 independent a)

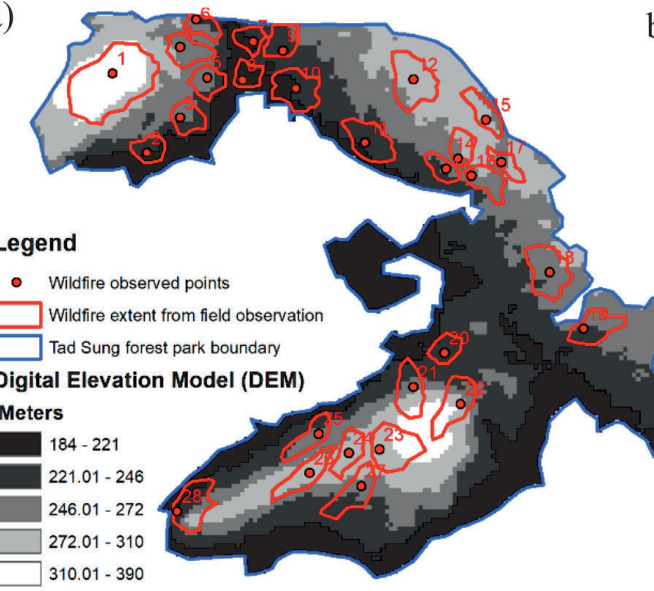

b)

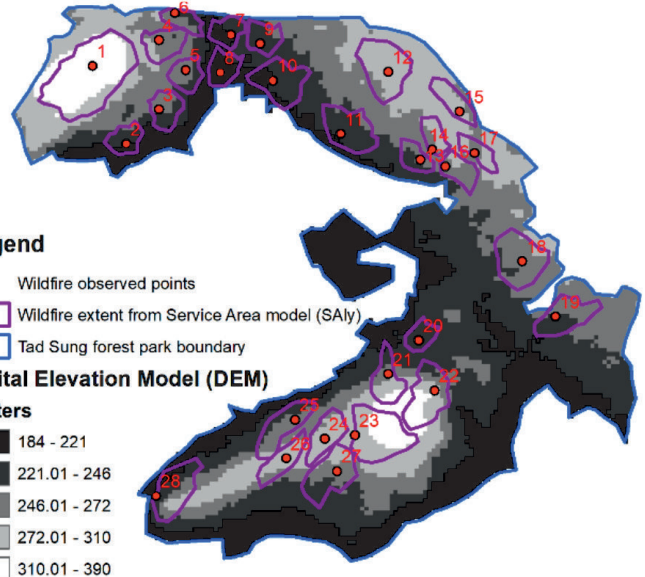

c)

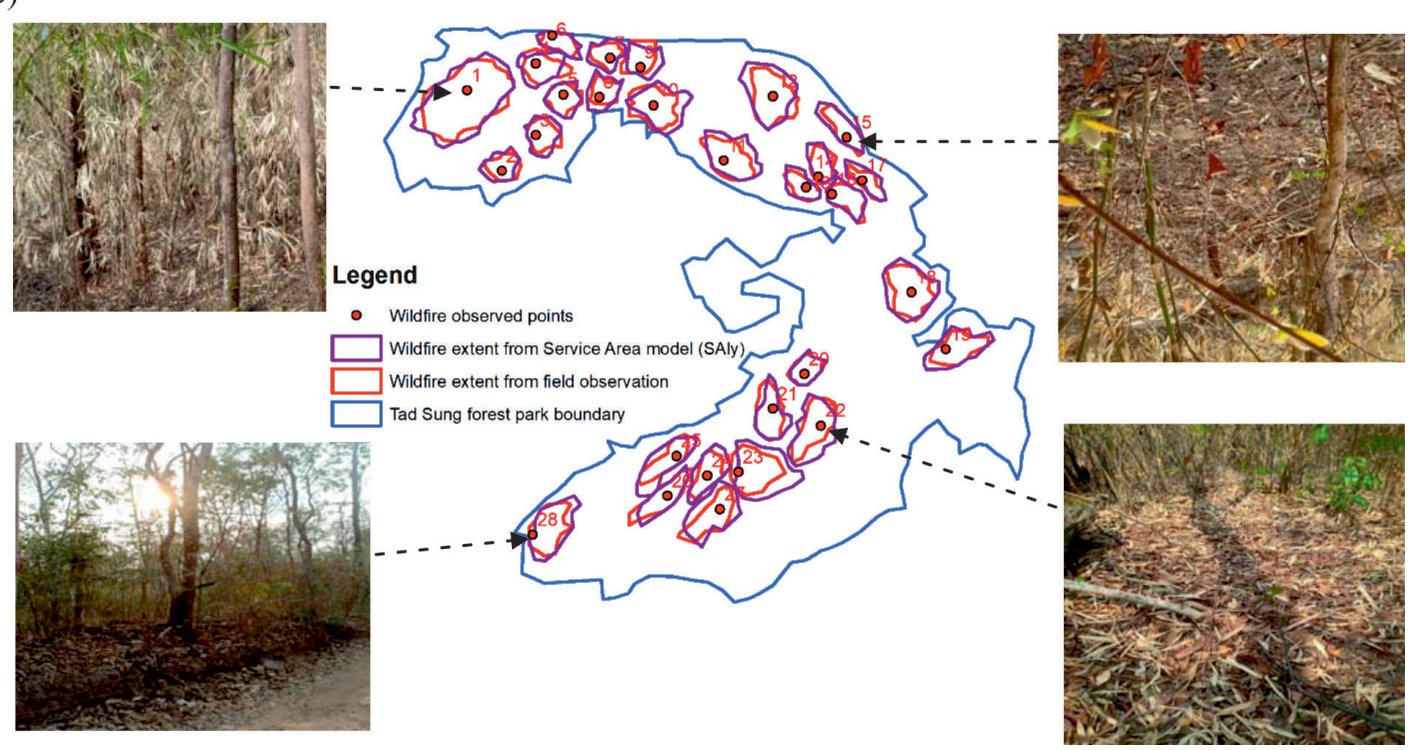

Fig. 4. Maps of wildfire extent: a) field observation, b) from $S A_{L Y}$ model, and c) from a combination of field observations and $S A_{L Y}$ model. 
variables are created as raster data in order to calculate the average and create an index as mentioned above. The variables used to import into the GWR model are shown in Fig. 5(a-g).

a)

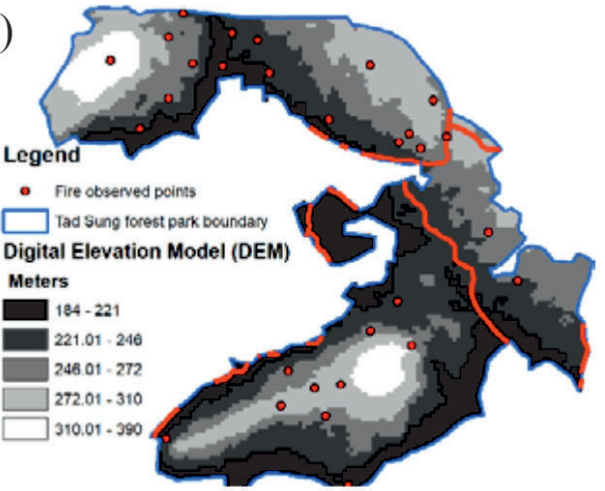

c)

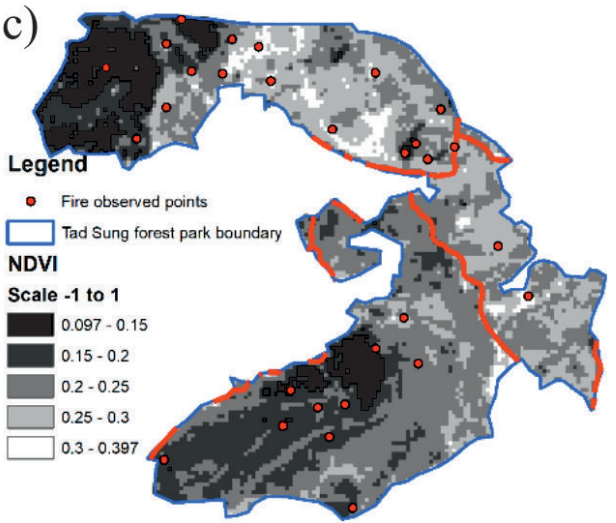

e)

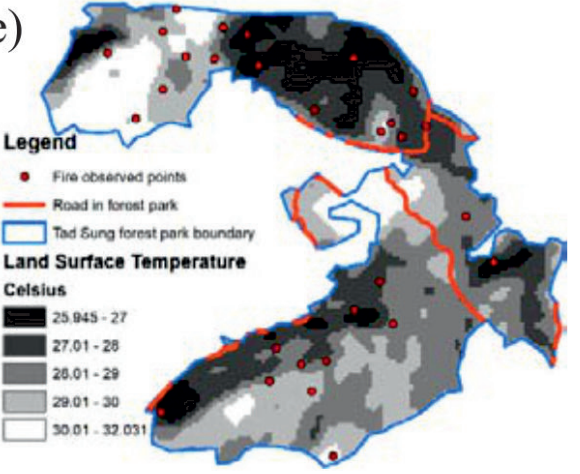

The summary results of the wildfire-GWR model is shown in Tables 2 and 3. Table 2 summarizes the results of the global and wildfire-GWR models of the study areas in Tad Sung Forest Park. The Monte

b)

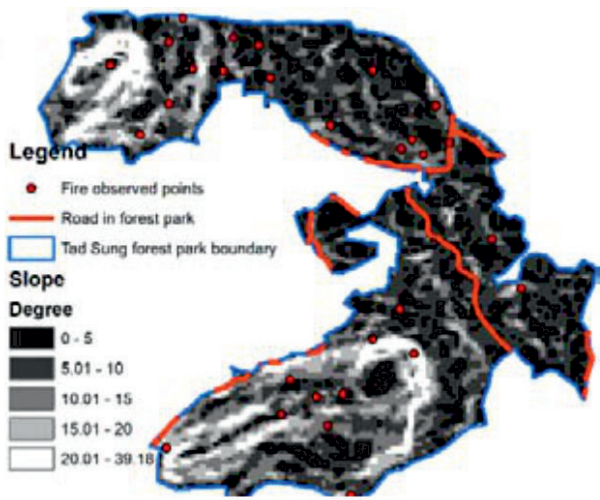

d)
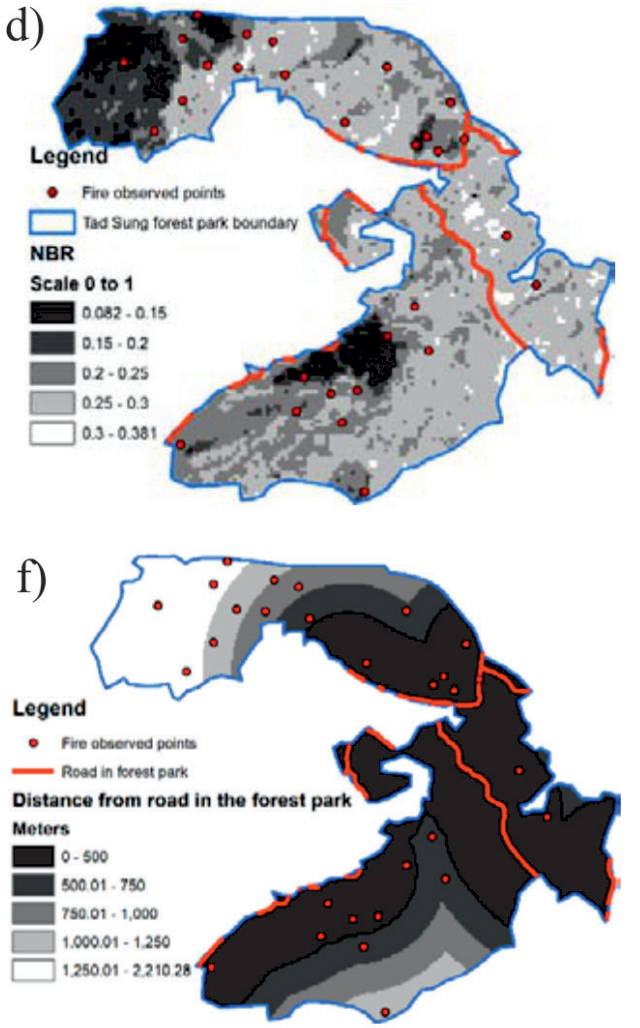

g)

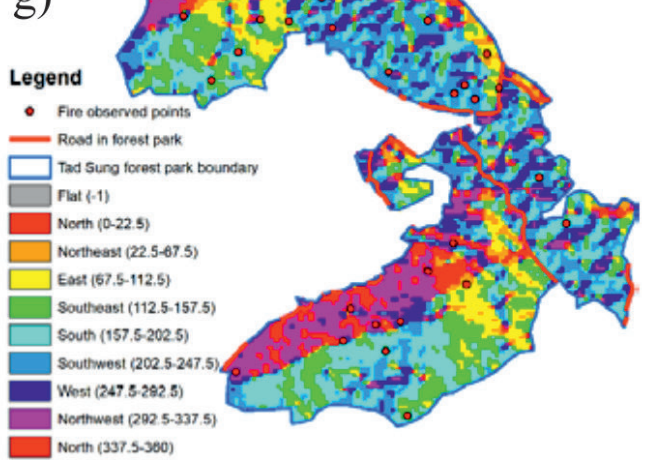

Fig. 5. Maps of independent variables in raster format used in the GWR model for spatial wildfire relationships a) to g). 
Table 2. Summary of the results of the wildfire-GWR model.

\begin{tabular}{|c|c|c|c|}
\hline \multicolumn{4}{|c|}{ Wildfire-GWR model coefficients } \\
\hline \multirow{2}{*}{ Variables } & \multicolumn{2}{|c|}{ GLOBAL } & GWR \\
\hline & $\beta$ & $\mathrm{t}$ & p-value ${ }^{a}$ \\
\hline Intercept & 43.76 & $5.28 * * *$ & $0.00 * * *$ \\
\hline DEM Index $\left(A D_{j}, X 1\right)$ & 28.07 & $2.67 * * *$ & $0.01 * * *$ \\
\hline Slope $\left(A S_{j}, X 2\right)$ & 24.00 & $3.95 * * *$ & $.01 * * *$ \\
\hline $\operatorname{NDVI}\left(A N D V I_{j}, X 3\right)$ & -0.49 & $-3.18 * * *$ & $0.00 * * *$ \\
\hline $\operatorname{NBR}\left(A N B R_{j}, X 4\right)$ & 4.82 & $6.58 * * *$ & $0.00 * * *$ \\
\hline $\operatorname{LST}\left(A L S T_{j}, X 5\right)$ & 0.57 & $3.10 * * *$ & $0.00 * * *$ \\
\hline Aspect $\left(A A_{j}, X \emptyset\right)$ & -0.48 & $-2.17 * * *$ & $0.00 * * *$ \\
\hline Distance from road $\left(A D I S_{j}, X 7\right)$ & -0.04 & $-0.32 \mathrm{n} / \mathrm{s}$ & $0.91 \mathrm{n} / \mathrm{s}$ \\
\hline $\mathrm{N}$ & 28 & & \\
\hline Adjusted $\mathrm{R}^{2}$ & 0.64 & & 0.82 \\
\hline
\end{tabular}

$* * *=$ significant at $1 \%$ level

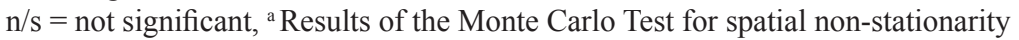

Table 3. ANOVA test of the wildfire-GWR over the OLS regression model

\begin{tabular}{|c|c|c|c|c|}
\hline Source & SS & DF & MS & F \\
\hline OLS Residuals & 46312.3 & 20.0 & & \\
\hline GWR Improvement & 17132.5 & 384.42 & 3.69 & \\
\hline GWR Residuals & 19281.5 & 2795.43 & 5.81 & 7.185 \\
\hline GWR Akaike Information Criterion & 13737.1 & (OLS): 20234.1 & & \\
\hline
\end{tabular}

Carlo Test summary table and the wildfire-GWR model calibration found that 6 out of the 7 significant independent variables show spatial non-stationarity $[48,49]$. In addition, the GWR model has an $\mathrm{R}^{2}$ level precision at $82 \%$, which is greater than the global model $\left(\mathrm{R}^{2}=0.64\right)$. The extent of the spreading of wildfire in the sub-area with low $\mathrm{R}^{2}$ may be affected to a greater degree by other factors that are not considered in this study, and there may also be fringe effects that are not considered in this study [49]. In the local operation of GWR, an F-test is also used to test whether spatial changes exist in the relationship under the study [49], specifically testing whether the GWR model is updated and explaining the relationship significantly over the general global operation using ordinary least squares (OLS).

This concern was addressed through the testing using ANOVA for the creation in the study area. The F-value is 7.185. The high F-value suggests that the GWR format is significantly improved through a global form to define the relationship between the wildfire spreading and different factors [48, 49]. Additionally, the Akaike information (AIC) of the GWR format $(13,737.1)$ is far less than one of the global operations
$(20,234.1)$. This indicates that the GWR local operation is improved to a greater extent than the OLS model [48, 49] (referenced in Table 3). The wildfire-GWR model is shown in (Eq. 13).

$$
\begin{aligned}
\text { Wildfire } & =5.28+2.67 D E M+3.95 \text { Slope }-3.18 N D V I \\
& +6.58 N B R+3.10 L S T-2.17 \text { Aspect }
\end{aligned}
$$

The model can be processed to analyze variables that have a positive impact on the spread, including $A D_{j}$ (DEM), $A S_{j}$ (Slope), $A N B R_{j}$ (NBR) and $A L S T_{j}$ (LST). The DEM and Slope factors are consistent with the acceleration of wildfires at a similar level, as they are created based on high-altitude values. The spread rate of wildfire is faster in areas of varying heights, over 10 meters per distance of 30 meters and the area with a slope of more than 10 degrees will be the same as $A D_{j}$ (DEM). The thermal reflection variables, both $A L S T_{j}$ (LST) and $A N B R_{j}$ (NBR), are factors that promote the progression of wildfires together, because the moisture of the smaller surface makes the fire spread faster.

The $A N D V I_{j}$ (NDVI) and $A_{j}$ (Aspect) factors affect the aforementioned variables on the progression of fire. 
In an indirect way, the NDVI index is lower, meaning that the area will have a large leaf fall. This causes a fuel to be easily spread, and most plants are mixed deciduous forest wood and bamboo forests, making it possible to quickly spread the fire in an area where NDVI has a low value.

The aspect factor sets the score of the slope direction into 8 ranges, giving the north a value of 1 , the northeast 2, and the other clockwise directions then determined to have scores up to 8 . The results of the model represent the finding that a slope direction that is in the northeast and the east will affect the progression of wildfire over the others, as the influence of the local wind is encouraged to blow the fire to spread faster.

The $A D I S_{j}$ (average of distance) factor is rarely involved in the progression of wildfire, because the road network characteristics in the area are rarely connected and the villagers conducting activities in the forest will park their cars in close proximity to the street and walk into the distant area in the forest within a distance of more than $500 \mathrm{~m}$. This is largely the cause of this factor not influencing the progression of wildfire. But in addition to the results of the analytical models, the travel factor affecting human-caused fires is considered the main factor in the wildfires in the Tad Sung Forest Park area, but because these values cannot be measured as points, they do not contribute to the analysis. Models can be used with future year variables to predict wildfires. The index of independent variables can be created from satellite imagery.

\section{Conclusions}

Forest fire control has been set to have a complete system of forest fire management and solutions. In other words, starting from the prevention of wildfire, it is a study of the cause of wildfire in each region, and then plan to prevent or eliminate the cause of a forest fire. If the forest burns, the fire will not be in practice, but even with the protection of forest fires, it is not possible to prevent $100 \%$ [2]. Forest fires are also likely to occur. As a result, the preparation of the forest fires, fire detection, forest fires, and performance assessments are necessary. However, it turns out that fire is useful in forest management. In many ways, therefore, it is also possible to take advantage of fire in tandem [9].

This study model can be used as a prototype to analyze the boundaries of the progression of wildfire. It can be used in forest areas with mixed deciduous forests and drought. This study confirmed that the service area model $\left(S A_{L Y}\right.$ model) can be used to analyze the boundaries of wildfires. It was shown to be close to the actual event by checking with the data from the TRF (Thai Royal Forest) and DNP (Department of National Parks, Thailand) of the Tad Sung area using the ignition information during the years 2013-2019 [1].

The use of models in other areas means it is necessary to be aware of the cut-off configuration to be able to find the boundaries of the progression of the fire. The model can be used on the basis of network analysis with the service area function of both the ArcGIS and QGIS programs, but in this analysis, it is necessary to create a network resistance/impedance to suit the problem and spatial characteristics [49]. This study can be used to predict the spread of wildfires in mixed deciduous forest areas in this way.

\section{Acknowledgements}

This research project is financially supported by the Faculty of Informatics, Mahasarakham University (Fast Track 2019) and the Research Unit of Geo-Informatics for Local Development and Climate Change, Mitigation and Adaptation Research Unit; CMARE). This study must thank Dr. Satith Sangpradid, Dr. Nutchanat Buasri, Mr. Komkrit Wongpakham and Ms. Benjamabhorn Pumhirunroj for information on a variety of crops that have the opportunity to create fuels for wildfire and a variety of wildlife habitats.

\section{Conflict of Interest}

All the authors declare no conflict of interest.

\section{References}

1. THAI ROYAL FOREST (TRF). Available online: https:// wildfire.forest.go.th/archives/category/, (accessed on 15 JULY 2019).

2. OMID G., THOMAS B., KHALIL G., JAGANNATH A. Forest Fire Susceptibility and Risk Mapping Using Social/ Infrastructural Vulnerability and Environmental Variables. Fire, 2, 50, 2019.

3. LIU Q., SHAN Y., SHU L., SUN P., DU S. Spatial and temporal distribution of forest fire frequency and forest area burnt in Jilin Province, Northeast China. J. For. Res, 29, 1233, 2018.

4. PRESTON B., BROOKE C., MEASHAM T.G., SMITH T., GORDDARD R. Igniting change in local government: Lessons learned from a bushfire vulnerability assessment. Mitig. Adapt. Strateg. Glob. Chang, 14, 251, 2009.

5. AHN Y.S., RYU S.R., LIM, J., LEE C.H., SHIN J.H., CHOI W.I., LEE B., JEONG J.H., AN K.W., SEO J.I. Erratum to: Effects of forest fires on forest ecosystems in eastern coastal areas of Korea and an overview of restoration projects. Landsc. Ecol. Eng, 10, 239. 2014.

6. CHOWDHURY E.H., HASSAN Q.K. Operational perspective of remote sensing-based forest fire danger forecasting systems. ISPRS J. Photogramm. Remote. Sens, 104, 224, 2015.

7. POURGHASEMI H.R. GIS-based forest fire susceptibility mapping in Iran: A comparison between evidential belief function and binary logistic regression models. Scand. J. For. Res, 31, 80, 2016.

8. DARVISHSEFAT A., MOSTAFAVI M., ETEMAD V., JAHDI R. Wind Effect on Wildfire and Simulation of 
Its Spread (Case Study: Siahkal Forest in Northern Iran). J. Agr. Sci. Tech, 16, 1109, 2014.

9. MILLER C., AGER A.A. A review of recent advances in risk analysis for wildfire management. Int. J. Wildland Fire, 22, 1, 2013.

10. EMRICH C.T., BORDEN K.A., SCHMIDTLEIN M.C., PIEGORSCH W.W., CUTTER S.L. Vulnerability of U.S. Cities to Environmental Hazards. J. Homel. Secur. Emerg. Manag, 4, 4, 2007.

11. MEENA S.R., MISHRA B.K., PIRALILOU S.T. A Hybrid Spatial Multi-Criteria Evaluation Method for Mapping Landslide Susceptible Areas in Kullu Valley, Himalayas. Geosciences, 9, 156, 2019.

12. SHAHABI H., HASHIM M. Landslide susceptibility mapping using GIS-based statistical models and Remote sensing data in tropical environment. Sci. Rep, 5, 9899, 2015.

13. EIDSVIG U.M.K., MCLEAN A., VANGELSTEN B.V., KALSNES B., CIUREAN R.L., ARGYROUDIS S., WINTER M.G., MAVROULI O.C., FOTOPOULOU S., PITILAKIS K. Assessment of socioeconomic vulnerability to landslides using an indicator-based approach: Methodology and case studies. Bull. Int. Assoc. Eng. Geol, 73, 307, 2014.

14. VAN WESTEN C. Remote Sensing and GIS for Natural Hazards Assessment and Disaster Risk Management. Treatise Geomorphol, 3, 259, 2013.

15. DWYER A., ZOPPOU C., NIELSEN O., DAY S., ROBERTS S. Quantifying Social Vulnerability: A Methodology for Identifying Those at Risk to Natural Hazards; Australian Government: Canberra, Australia, 2004.

16. ARYAL J., LOUVET R. Quantifying Bushfire Mapping Uncertainty Using Single and Multi-Scale Approach: A Case Study from Tasmania, Australia. In Proceedings of the GEOBIA 2016: Solutions and Synergies, Twenty, The Netherlands, 14-16 September, 2016.

17. POURGHASEMI H.R., RAHMATI O. Prediction of the landslide susceptibility: Which algorithm, which precision? Catena, 162, 177-192, 2018.

18. MEENA S.R., GHORBANZADEH O., BLASCHKE T. A Comparative Study of Statistics-Based Landslide Susceptibility Models: A Case Study of the Region Affected by the Gorkha Earthquake in Nepal. ISPRS Int. J. Geo-Inf, 8, 94, 2019.

19. MCCAFFREY S., TOMAN E., STIDHAM M., SHINDLER B. Social science research related to wildfire management: An overview of recent findings and future research needs. Int. J. Wildland Fire, 22, 15, 2013.

20. WIGTIL G., HAMMER R.B., KLINE J.D., MOCKRIN M.H., STEWART S.I., ROPER D., RADELOFF V.C. Places where wildfire potential and social vulnerability coincide in the coterminous United States. Int. J. Wildland Fire, 25, 896, 2016.

21. LUECK D., YODER J. Clearing the Smoke from Wildfire Policy: An Economic Perspective; PERC: Bozeman, MT, USA, 2016

22. CHUVIECO E., MARTÍNEZ S., ROMÁN M.V., HANTSON S., PETTINARI M.L. Integration of ecological and socio-economic factors to assess global vulnerability to wildfire. Glob. Ecol. Biogeogr, 23, 245, 2014.

23. MUKHIDDIN J., ALIM P., SVEN F., JOHANNES H. Analysis of Land Use Land Cover Change Detection of Bostanlik District, Uzbekistan. Pol. J. Environ. Stud, 28 (5), 3235, 2019
24. RAWAT J.S., KUMAR M. Monitoring land use/cover change using remote sensing and GIS techniques: A case study of Hawalbagh block, district Almora, Uttarakhand, India. The Egyptian Journal of Remote Sensing and Space Science, 18 (1), 77, 2015.

25. TURNER M.G., RUSCHER C.L. Changes in landscape patterns in Georgia, USA. Landscape Ecology, 1 (4), 241, 1988.

26. YANG A., SUN G. Landsat-Based Land Cover Change in the Beijing-Tianjin-Tangshan Urban Agglomeration in 1990, 2000 and 2010. ISPRS International Journal of Geo- Information, 6 (3), 59, 2017.

27. GONG P., WANG J., YU L., ZHAO Y., ZHAO Y., LIANG L., CHEN J. Finer resolution observation and monitoring of global land cover: first mapping results with Landsat $\mathrm{TM}$ and ETM+ data. International Journal of Remote Sensing, 34 (7), $2607,2013$.

28. KEY C.H., BENSON N. Landscape Assessment (LA). FIREMON: Fire Effects Monitoring and Inventory System; U.S.Department of Agriculture, Forest Service, Rocky Mountain Research Station: Fort Collins, CO, USA, LA, 1, 2006.

29. ROUSE J.W., JR., HAAS R., SCHELL J., DEERING D. Monitoring Vegetation Systems in the Great Plains with ERTS; Texas A\&M Univ.: College Station, TX, USA, 1974.

30. MILLER J.D., THODE A.E. Quantifying burn severity in a heterogeneous landscape with a relative version of the delta Normalized Burn Ratio (dNBR). Remote Sens. Environ. 109, 66, 2007.

31. VAN WAGTENDONK J.W., VAN WAGTENDONK K.A. THODE A.E. Factors associated with the severity of intersecting fires in Yosemite National Park, California, US. Fire Ecol., 8, 11, 2012.

32. PARKS S., DILLON G., MILLER C. A new metric for quantifying burn severity: The Relativized Burn Ratio. Remote Sens., 6, 1827, 2014.

33. LYDERSEN J.M., NORTH M.P., COLLINS B.M. Severity of an uncharacteristically large wildfire, the Rim Fire, In forests with relatively restored frequent fire regimes. For. Ecol. Manag., 328, 326, 2014.

34. PICOTTE J.J., PETERSON B.E., MEIER G., HOWARD S.M. 1984-2010 trends in fire burn severity and area for the conterminous US. Int. J. Wildland Fire, 25, 413, 2016.

35. COPPOLETTA M., MERRIAM K.E., COLLINS B.M. Post-fire vegetation and fuel development influences fire severity patterns in reburns. Ecol. Appl., 26, 686, 2016.

36. SMITH A.M.S., WOOSTER M.J., DRAKE N.A., DIPOTSO F.M., FALKOWSKI M.J., HUDAK A.T. Testing the potential of multi-spectral remote sensing for retrospectively estimating fire severity in African Savannahs. Remote Sens. Environ. 97, 92, 2005.

37. ROY D.P., BOSCHETTI L., TRIGG S.N. Remote Sensing of fire severity: Assessing the performance of the Normalized Burn Ratio. IEEE Geosci. Remote Sens., 3, 112,2006

38. EDWARDS A.C., MAIER S.W., HUTLEY L.B., WILLIAMS R.J., RUSSELL-SMITH J. Spectral analysis of fire severity in north Australian tropical savannas. Remote Sens. Environ, 136, 56, 2013.

39. LOZANO F.J., SUÁREZ-SEOANE S., DE LUIS E. Assessment of several spectral indices derived from multitemporal Landsat data for fire occurrence probability modelling. Remote Sens. Environ, 107, 533, 2007.

40. ESCUIN S., NAVARRO R., FERNANDEZ P. Fire severity assessment by using NBR (Normalized Burn Ratio) and 
NDVI (Normalized Difference Vegetation Index) derived from LANDSAT TM/ETM+ images. Int. J. Remote Sens, 29, 1053, 2008.

41. LECINA-DIAZ J., ALVAREZ A., RETANA J. Extreme fire severity patterns in topographic, convective and winddriven historical wildfires of Mediterranean pine forests. PLoS ONE, (9), e85127, 2014.

42. ALLEN J.L., SORBEL B. Assessing the differenced Normalized Burn Ratios ability to map burn severity in the boreal forest and tundra ecosystems of Alaskas national parks. Int. J. Wildland Fire, 17, 463, 2008.

43. HALL R.J., FREEBURN J.T., DE GROOT W.J., PRITCHARD J.M., LYNHAM T.J., LANDRY R. Remote sensing of burn Severity: Experience from western Canada boreal fires. Int. J. Wildland Fire, 17, 476, 2008.

44. CHAFER C.J. A comparison of fire severity measures: An Australian example and implications for predicting major areas of soil erosion. Catena, 74, 235, 2008.

45. CLARKE P.J., KNOX K.J.E., BRADSTOCK R.A., MUNOZ-ROBLES C., KUMAR L. Vegetation, terrain and fire history shape the impact of extreme weather on fire severity and ecosystem response. J. Veg. Sci., 25, 1033, 2014.

46. TANASE M.A., KENNEDY R., APONTE C. Fire severity estimation from space: A comparison of active and passive sensors and their synergy for different forest types. Int. J.Wildland Fire, 24, 1062, 2015.

47. BOER M.M., MACFARLANE C., NORRIS J., SADLER R.J., WALLACE J., GRIERSON P.F. Mapping burned areas and burn severity patterns in SW Australian eucalypt forest using remotely-sensed changes in leaf area index. Remote Sens. Environ, 112, 4358, 2008.

48. NORESAH M.S., RUSLAN R. Modelling urban spatial structure using Geographically Weighted Regression. $18^{\text {th }}$ World IMACS / MODSIM Congress, Cairns, Australia 1317 July. Available online: http://mssanz.org.au/modsim09, 1950-1956, (accessed on 25 JULY 2019).

49. PATIWAT L., NUTCHANAT B. Built-Up Growth Impacts on Digital Elevation Model and Flood Risk Susceptibility Prediction in Muaeng District, Nakhon Ratchasima (Thailand). Water, 11 (7), 1496, 2019.

50. SAYAD Y.O., MOUSANNIF H., AL MOATASSIME H. Predictive modeling of wildfires: A new dataset and machine learning approach. Fire Saf. J, 104, 130, 2019.

51. GHORBANZADEH O., FEIZIZADEH B., BLASCHKE T. Multi-criteria risk evaluation by integrating an analytical network process approach into GIS-based sensitivity and uncertainty analyses. Geomat. Nat. Hazards Risk, 9, 127, 2018.
52. HAMID R.P., MASOOD B., BISWAJEET P. A comparative assessment of prediction capabilities of modified analytical hierarchy process (M-AHP) and Mamdani fuzzy logic models using Netcad-GIS for forest fire susceptibility mapping, Geomatics, Natural Hazards and Risk, 7 (2), 861, 2016.

53. GHORBANZADEH O., BLASCHKE T. Wildfire susceptibility evaluation by integrating an analytical network process approach into GIS-based analyses. Int. J. Adv. Sci. Eng. Technol., 6, 48, 2018.

54. DUTTA R., DAS A., ARYAL J. Big data integration shows Australian bush-fire frequency is increasing significantly. R. Soc. Open Sci., 3, 150, 2016.

55. YU X. Disaster prediction model based on support vector machine for regression and improved differential evolution. Nat. Hazards, 85, 959, 2017.

56. SAKR G.E., ELHAJJ I.H., MITRI G., WEJINYA U.C. Artificial intelligence for forest fire prediction. In Proceedings of the 2010 IEEE/ASME International Conference on Advanced Intelligent Mechatronics (AIM), Montreal, QC, Canada, 6-9 July, IEEE: Piscataway, NJ, USA, 1311, 2010.

57. ABDOLLAHI S., POURGHASEMI H.R., GHANBARIAN G.A., SAFAEIAN R. Prioritization of effective factors in the occurrence of land subsidence and its susceptibility mapping using an SVM model and their different kernel functions. Bull. Eng. Geol. Environ., 1, 2018.

58. VALDEZ M.C., CHANG K.T., CHEN C.F., CHIANG, S.H., SANTOS J.L. Modelling the spatial variability of wildfire susceptibility in honduras using remote sensing and geographical information systems. Geomat. Nat. Hazards Risk, 8, 876, 2017.

59. ARPACI A., MALOWERSCHNIG B., SASS O., VACIK H. Using multi-variate data mining techniques for estimating fire susceptibility of Tyrolean forests. Appl. Geogr, 53, 258, 2014.

60. USGS. Product guide Landsat surface reflectance derived spectral indices. Available online: https://landsat.usgs. gov/sites/default/files/documents/si_product_guide.pdf, (accessed on 18 JULY 2019).

61. PATIWAT L., SUNYA S. Positioning ambient air quality monitoring stations utilizing spatial multi-objective decision analyses. Pollution Research, 35 (3), 429, 2016.

62. FOTHERINGHAM A.S., BRUNSDON C., CHARLTON M. Geographically Weighted Regression: The Analysis of Spatially Varying Relationships; John Wiley and Sons Ltd.: West Sussex, UK, 2002. 
